\title{
Computation of correlations of fortified vermicompost with sulphur on seed yield and nutrient content of mustard [Brassica juncea]
}

\author{
Suman Parihar $^{1 *}$, P. R. Kameriya ${ }^{2}$ and Rakesh Choudhary ${ }^{3}$ \\ ${ }^{1}$ Department of Soil Science and Agricultural Chemistry, Sri Karan Nerandra Agricultural University, Jobner-303329 \\ (Rajasthan), INDIA \\ ${ }^{2}$ Department of Soil Science and Agricultural Chemistry, College of Agriculture, Bikaner-334006 (Rajasthan), INDIA \\ ${ }^{3}$ Subject Matter Specialist (Agronomy), Krishi Vigyan Kendra, Ambala (Haryana), INDIA \\ *Corresponding author. E-mail: pariharsuman30@gmail.com
}

Received: January 8, 2015; Revised received: March 12, 2016; Accepted: June 1, 2016

\begin{abstract}
Effect of sulphur and fortified vermicompost on growth and yield of mustard [Brassica juncea] was carried out at College of Agriculture, Swami Keshwanand Rajasthan Agricultural University, Bikaner (Rajasthan) during rabi season: 2010-11. Sixteen treatment combinations comprising four levels of each sulphur and fortified vermicompost were evaluated. Grain yield $\left(1993 \mathrm{~kg} \mathrm{ha}^{-1}\right)$ increased significantly $(p<0.05)$ up to $6.0 \mathrm{t}$ vermicompost ha ${ }^{-1}$ along with $40 \mathrm{~kg}$ sulphur ha-1. As regards interactive effects of treatment, synergistic behavior was noted between $6.0 \mathrm{t}$ vermicompost ha ${ }^{-1} 40 \mathrm{~kg} \mathrm{~S}^{-1}$ for seed yield, nitrogen, and phosphorus contents and also sulphur content and uptake by seed of mustard. The significantly higher $P$ content in seed was recorded under $40 \mathrm{~kg} \mathrm{~S}^{-1}$ in combination with 4.0 $\mathrm{t} \mathrm{ha} \mathrm{h}^{-1}$ vermicompost Combined effect of levels of vermicompost and sulphur on seed yield was found to be significant than control. The concomitant effect of $6.0 \mathrm{t}_{\text {vermicompost ha- }}^{-1}$ and $40 \mathrm{~kg} \mathrm{~S} \mathrm{ha}^{-1}$ application was found highly pronounced on seed yield and sulphur content in seed of mustard.
\end{abstract}

Keywords: Computation, Nutrient content, Sulphur uptake, Vermicompost, Yield

\section{INTRODUCTION}

Mustard [Brassica juncea (L) Czern and Coss] is the second most important oilseed crop in India next to groundnut. India is the third largest producer of rapeseed-mustard (Piri et al., 2011) having 5.90 million hectares area with 6.41 million tonnes production, but the average yield of rapeseed-mustard in India is only $1145 \mathrm{~kg} / \mathrm{ha}$ (Economic survey, 2013). The sulphur requirement of oilseed crops is known to be high and increase in the production of mustard due to the application of sulphur have been reported by Aulakh et al. (1977). Application of sulphur was reported to increase yield attributes and yield of Indian mustard (Patel et al. 2009, Kumar et al., 2011), which also has a significant effect on oil, fatty acid (Ahmad and Abdin 2000) and glucosinolates content in mustard seed (Falk et al., 2007). The relative proportions of individual glucosinolates viz. sinigrin (allyl isothio-cyanate), gluconapin (3-butenyl glucosinolate) and progoitrin (2-hydroxy-3butenyl glucosinolate) are influenced by sulphur application (Hassan et al., 2007).

Balance fertilization through organic and inorganic sources collectively improves the yield and soil health. Incorporation of organic residues directly or indirectly also improves the physical properties of soil and helps in sustaining the crop production (Swarup and Wanjari, 2000). A field experiment conducted to find out the effect of organic manure fortified with micronutrients viz., $\mathrm{ZnSO}_{4}$ and $\mathrm{FeSO}_{4}$ on the growth and yield of rice in coastal saline soil showed that, micronutrients fortified composted green leaf manure significantly increased the growth and yield parameters of rice as compared to other treatments Kamaraj et. al. (2010). Sulphur being a component of amino acids is involved in the quality and productivity of mustard. The present study was therefore conducted to study the response of vermicompost and sulphur on the growth and yield of mustard [Brassica juncea].

\section{MATERIALS AND METHODS}

A field experiment was conducted at the Agronomy farm of college of Agriculture, Bikaner during Rabi of 2010 using mustard cv. Bio-902 (Pusa Jai Kisan) as the test crop. The experimental soil was loamy sand, low in available $\mathrm{N}, \mathrm{P}, \mathrm{K}$ and $\mathrm{S}\left(113,20,114 \mathrm{~kg} \mathrm{ha}^{-1}\right.$ and $8.5 \mathrm{mg} \mathrm{kg}^{-1}$, respectively). The soil was non saline with a reaction 8.5 and low organic carbon $(0.13 \%)$. Treatments consisted of 16 combinations i.e. four levels of fortified vermicompost, namely control $\left(\mathrm{V}_{0}\right), 2\left(\mathrm{~V}_{2}\right), 4$ $\left(\mathrm{V}_{4}\right)$, and $6\left(\mathrm{~V}_{6}\right) \mathrm{t} \mathrm{ha}^{-1}$ and four levels of sulphur viz. control $\left(\mathrm{S}_{0}\right), 20\left(\mathrm{~S}_{20}\right), 40\left(\mathrm{~S}_{40}\right)$ and $60\left(\mathrm{~S}_{60}\right) \mathrm{kg} \mathrm{ha}^{-1}$ were replicated thrice and laid out in RBD. As per treatments, elemental sulphur and vermicompost were applied prior 
to sowing and recommended dose of nitrogen @ $90 \mathrm{~kg}$ ha -1 and phosphorus@40 kg ha ${ }^{-1}$ were applied as per treatment through Urea and DAP. Grain and stover yields were recorded at harvest, plant samples were analyzed using standard procedure (Snell and Snell, 1971; Jackson, 1967; Tabatabai and Bremmer, 1970) for $\mathrm{N}, \mathrm{P}$ and $\mathrm{S}$, respectively. All agronomic practices were carried out uniformly for all treatments. After threshing and winnowing, the clean seeds obtained from the produce of individual plot were weighed and weight was recorded as seed yield $\mathrm{kg}$ /

\begin{tabular}{|c|c|c|c|c|c|}
\hline \multirow[t]{2}{*}{$\begin{array}{l}\text { Nutrient } \\
\text { uptake }= \\
\left(\mathrm{kg} \mathrm{ha}^{-1}\right)\end{array}$} & $\begin{array}{c}\text { Per cent } \\
\text { nutrient } \\
\text { content in } \\
\text { seed } \\
\end{array}$ & $\begin{array}{c}\text { Seed } \\
\text { x yield }(\mathrm{kg} \\
\left.\mathrm{ha}^{-1}\right) \\
\end{array}$ & $\begin{array}{r}\text { Per cent } \\
\text { nutrient } \\
+\quad \text { content } \\
\text { in straw } \\
\end{array}$ & $x$ & $\begin{array}{c}\text { Straw yield } \\
\left(\mathrm{kg} \mathrm{ha}^{-1}\right)\end{array}$ \\
\hline & \multicolumn{5}{|c|}{100} \\
\hline
\end{tabular}

plot. Later, this was converted into $\mathrm{q} \mathrm{ha}^{-1}$.The uptake of nitrogen, phosphorus, potassium and sulphur at harvest in seed and stover were estimated by using the following formula:

For estimation of nutrient content representative samples of seed and stover were taken at the time of threshing. Each dried seed and stover samples were ground to fine powder in an electric grinder. Nitrogen, phosphorus, potassium and sulphur in seed and stover were estimated by using standard methods given in Table 1 .

\section{RESULTS}

Seed yield

Effect of vermicompost: The seed yield increased significantly with increasing levels of fortified vermicompost (Table 7). The maximum seed yield (1865.0 $\mathrm{kg} \mathrm{ha}{ }^{-1}$ ) was observed under the treatment $\mathrm{V}_{6.0}$ while

Table1: Methods for plant analysis.

\begin{tabular}{|c|c|c|c|}
\hline S. No & Determination & Methods & References \\
\hline 1 & $\begin{array}{l}\text { Digestion of plant sam- } \\
\text { ples-I }\end{array}$ & Wet digestion of plant samples with $\mathrm{H}_{2} \mathrm{SO}_{4}$ and $\mathrm{H}_{2} \mathrm{O}_{2}$ & Jackson (1967) \\
\hline 2 & Nitrogen content & $\begin{array}{l}\mathrm{N} \text { was estimated by colorimetric method on spectronic- } 20 \text { after } \\
\text { development of colour with Nesseler's reagent }\end{array}$ & Snell and Snell (1939) \\
\hline 3 & $\begin{array}{l}\text { Digestion of plant sam- } \\
\text { ples-II }\end{array}$ & $\begin{array}{l}\text { Wet digestion of plant samples with di-acid mixture as per the } \\
\text { method described }\end{array}$ & Johnson and Ulrich (1959) \\
\hline 4 & Phosphorus content & $\begin{array}{l}\text { Phosphorus was estimated on spectronic- } 20 \text { by using Vando- } \\
\text { molybdo phosphoric yellow colour method in nitric acid system }\end{array}$ & Jackson (1967) \\
\hline 5 & Sulphur content & By colorimeteric measurement method & $\begin{array}{l}\text { Tabatabai and Bremmer } \\
\text { (1970) }\end{array}$ \\
\hline
\end{tabular}

Mean weekly meteorological data for crop season $(r a b i, 2010)$ were optimum for potential crop growth and production (Fig.1).

Table 2: Interaction effect between vermicompost and sulphur on seed yield of mustard.

\begin{tabular}{llllll}
\hline \multirow{2}{*}{$\begin{array}{l}\text { Sulphur levels } \\
\left(\mathrm{kg} \mathrm{S} \mathrm{ha}^{-1}\right)\end{array}$} & $\begin{array}{l}\text { Vermicompost levels }\left(\mathbf{t ~ h a} \mathbf{~}^{-1}\right) \\
\left(\mathrm{V}_{0}\right)\end{array}$ & $\begin{array}{l}2.0 \\
\left(\mathrm{~V}_{2}\right)\end{array}$ & $\begin{array}{l}\text { Control } \\
\left(\mathrm{V}_{4}\right)\end{array}$ & $\begin{array}{l}6.0 \\
\left(\mathrm{~V}_{6}\right)\end{array}$ & Mean \\
\hline Control $\left(\mathrm{S}_{0}\right)$ & 956 & 1151 & 1458 & 1589 & 1289 \\
$20\left(\mathrm{~S}_{20}\right)$ & 980 & 1369 & 1658 & 1862 & 1467 \\
$40\left(\mathrm{~S}_{40}\right)$ & 1107 & 1495 & 1796 & 1993 & 1598 \\
$60\left(\mathrm{~S}_{60}\right)$ & 1108 & 1496 & 1817 & 2016 & 1610 \\
Mean & 1038 & 1378 & 1682 & 1865 & \\
& $\mathrm{~V}$ & $\mathrm{~S}$ & $\mathrm{VXS}$ & & \\
S.Em \pm & 17.4 & 17.4 & 34.8 & & \\
CD $(5 \%)$ & 50.3 & 50.3 & 100.6 & & \\
\hline
\end{tabular}

Table 4: Interaction effect between vermicompost and sulphur on $P$ content in seed of mustard.

\begin{tabular}{lccccc}
\hline \multirow{2}{*}{$\begin{array}{l}\text { Sulphur levels } \\
\left(\mathrm{kg} \mathrm{S} \mathrm{ha}^{-1}\right)\end{array}$} & \multicolumn{5}{c}{ Vermicompost levels $\left(\mathbf{t ~ h a}^{-1}\right)$} \\
\cline { 2 - 6 } & $\begin{array}{c}\text { Control } \\
\left(\mathrm{V}_{0}\right)\end{array}$ & $\begin{array}{c}2.0 \\
\left(\mathrm{~V}_{2}\right)\end{array}$ & $\begin{array}{c}4.0 \\
\left(\mathrm{~V}_{4}\right)\end{array}$ & $\begin{array}{c}6.0 \\
\left(\mathrm{~V}_{6}\right)\end{array}$ & Mean \\
\hline Control $\left(\mathrm{S}_{0}\right)$ & 0.471 & 0.676 & 0.754 & 0.835 & 0.684 \\
$20\left(\mathrm{~S}_{20}\right)$ & 0.691 & 0.767 & 0.843 & 0.910 & 0.803 \\
$40\left(\mathrm{~S}_{40}\right)$ & 0.773 & 0.843 & 0.921 & 0.982 & 0.880 \\
$60\left(\mathrm{~S}_{60}\right)$ & 0.775 & 0.847 & 0.923 & 0.988 & 0.883 \\
Mean & 0.677 & 0.783 & 0.860 & 0.929 & - \\
$\mathrm{S} . \mathrm{Em} \pm$ & 0.023 & - & - & - & - \\
CD $(5 \%)$ & 0.065 & - & - & - & \\
\hline
\end{tabular}

Table 3: Interaction effect between vermicompost and sulphur on $\mathrm{N}$ content in seed of mustard.

\begin{tabular}{llllll}
\hline \multirow{2}{*}{$\begin{array}{l}\text { Sulphur leves } \\
\left(\mathrm{kg} \mathrm{S} \mathrm{ha}^{-1}\right)\end{array}$} & \multicolumn{5}{c}{ Vermicompost levels (t ha } \\
\cline { 2 - 6 } & $\begin{array}{l}\text { Control } \\
\left(\mathrm{V}_{0}\right)\end{array}$ & $\begin{array}{l}2.0 \\
\left(\mathrm{~V}_{2}\right)\end{array}$ & $\begin{array}{l}4.0 \\
\left(\mathrm{~V}_{4}\right)\end{array}$ & $\begin{array}{l}6.0 \\
\left(\mathrm{~V}_{6}\right)\end{array}$ & Mean \\
\hline Control $\left(\mathrm{S}_{0}\right)$ & 2.21 & 3.06 & 3.37 & 3.73 & 3.09 \\
$20\left(\mathrm{~S}_{20}\right)$ & 3.14 & 3.43 & 3.78 & 4.07 & 3.60 \\
$40\left(\mathrm{~S}_{40}\right)$ & 3.47 & 3.76 & 4.09 & 4.42 & 3.93 \\
$60\left(\mathrm{~S}_{60}\right)$ & 3.48 & 3.79 & 4.11 & 4.44 & 3.96 \\
Mean & 3.07 & 3.51 & 3.84 & 4.17 & - \\
S.Em \pm & 0.09 & - & - & - & - \\
CD $(5 \%)$ & 0.25 & - & - & - & - \\
\hline
\end{tabular}

Table 5: Interaction effect between vermicompost and sulphur on sulphur content in seed of mustard.

\begin{tabular}{lccccc}
\hline \multirow{2}{*}{$\begin{array}{l}\text { Sulphur levels } \\
\left(\mathrm{kg} \mathrm{S} \mathrm{ha}^{-1}\right)\end{array}$} & $\begin{array}{c}\text { Control } \\
\left(\mathrm{V}_{0}\right)\end{array}$ & $\begin{array}{c}2.0 \\
\left(\mathrm{~V}_{2}\right)\end{array}$ & $\begin{array}{c}4.0 \\
\left(\mathrm{~V}_{4}\right)\end{array}$ & $\begin{array}{c}6.0 \\
\left(\mathrm{~V}_{6}\right)\end{array}$ & Mean \\
\hline Control $\left(\mathrm{S}_{0}\right)$ & 0.453 & 0.770 & 0.938 & 1.018 & 0.795 \\
$20\left(\mathrm{~S}_{20}\right)$ & 0.687 & 0.854 & 0.993 & 1.107 & 0.910 \\
$40\left(\mathrm{~S}_{40}\right)$ & 0.766 & 0.925 & 1.070 & 1.202 & 0.991 \\
$60\left(\mathrm{~S}_{60}\right)$ & 0.780 & 0.933 & 1.077 & 1.205 & 0.999 \\
Mean & 0.672 & 0.871 & 1.019 & 1.133 & \\
$\mathrm{S.Em} \pm$ & 0.026 & & & & \\
$\mathrm{CD}(5 \%)$ & 0.075 & & & & \\
\hline
\end{tabular}


Table 6: Interaction effect between vermicompost and sulphur on sulphur uptake by seed of mustard.

\begin{tabular}{lccccc}
\hline \multirow{5}{*}{$\begin{array}{c}\text { Sulphur } \\
\text { levels } \\
\left(\mathbf{k g ~ S ~ h a}^{-1}\right)\end{array}$} & $\begin{array}{c}\text { Con- } \\
\text { trol } \\
\left(\mathbf{V}_{\mathbf{0}}\right)\end{array}$ & $\begin{array}{c}\mathbf{2 . 0} \\
\left(\mathbf{V}_{\mathbf{2}}\right)\end{array}$ & $\begin{array}{c}\mathbf{4 . 0} \\
\left(\mathbf{V}_{\mathbf{4}}\right)\end{array}$ & $\begin{array}{c}\mathbf{6 . 0} \\
\left(\mathbf{V}_{\mathbf{6}}\right)\end{array}$ & $\begin{array}{c}\text { Mea } \\
\mathbf{n}\end{array}$ \\
\hline Control $\left(\mathrm{S}_{0}\right)$ & 4.34 & 8.86 & 13.67 & 16.17 & 4.34 \\
$20\left(\mathrm{~S}_{20}\right)$ & 6.74 & 11.69 & 16.46 & 20.61 & 6.74 \\
$40\left(\mathrm{~S}_{40}\right)$ & 8.48 & 13.81 & 19.22 & 23.94 & 8.48 \\
$60\left(\mathrm{~S}_{60}\right)$ & 8.64 & 13.96 & 19.56 & 24.32 & 8.64 \\
Mean & 7.05 & 12.08 & 17.23 & 21.26 & 7.05 \\
$\mathrm{~S} . \mathrm{Em} \pm$ & 0.47 & - & - & - & 0.47 \\
$\mathrm{CD}(5 \%)$ & 1.35 & - & - & - & 1.35 \\
\hline
\end{tabular}

Rainfall ( $(\mathrm{mm})$

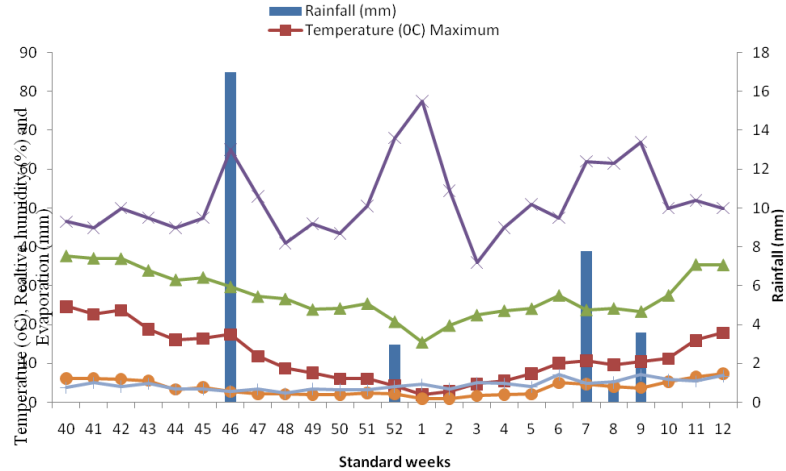

Fig.1. Mean weekly meteorological data during crop season Rabi, 2010-11. (Agricultural Research Station, Beechwal, Bikaner).

Table 7 : Effect of fortified vermicompost and sulphur levels on seed yield, nitrogen, phosphorus, sulphur (N, P\&S) content and sulphur uptake of mustard.

\begin{tabular}{|c|c|c|c|c|c|}
\hline Treatments & Seed Yield $\left(\mathrm{kg} \mathrm{ha}^{-1}\right)$ & $\mathrm{N}$ content $\%$ & P content \% & $S$ content $\%$ & S uptake $\mathrm{kg} \mathrm{ha}^{-1}$ \\
\hline \multicolumn{6}{|c|}{ Vermicompost levels $\left(\mathrm{tha}^{-1}\right)$} \\
\hline (i) Control & 1037.92 & 3.07 & 0.677 & 0.672 & 7.05 \\
\hline (ii) 2.0 & 1377.92 & 3.51 & 0.783 & 0.871 & 12.08 \\
\hline (iii) 4.0 & 1682.25 & 3.84 & 0.860 & 1.019 & 17.23 \\
\hline (iv) 6.0 & 1865.00 & 4.17 & 0.929 & 1.133 & 21.26 \\
\hline S.Em \pm & 17.41 & 0.04 & 0.011 & 0.013 & 0.23 \\
\hline $\mathrm{CD}(5 \%)$ & 50.29 & 0.12 & 0.033 & 0.038 & 0.68 \\
\hline \multicolumn{6}{|l|}{ Sulphur levels $\left(\mathrm{kg} \mathrm{Sha}^{-1}\right)$} \\
\hline (i) Control & 1288.50 & 3.09 & 0.684 & 0.795 & 10.76 \\
\hline (ii) 20 & 1467.08 & 3.60 & 0.803 & 0.910 & 13.87 \\
\hline (iii) 40 & 1598.00 & 3.93 & 0.880 & 0.991 & 16.36 \\
\hline (iv) 60 & 1609.50 & 3.96 & 0.883 & 0.999 & 16.62 \\
\hline S.Em \pm & 17.41 & 0.04 & 0.011 & 0.013 & 0.23 \\
\hline $\mathrm{CD}(5 \%)$ & 50.29 & 0.12 & 0.033 & 0.038 & 0.68 \\
\hline
\end{tabular}

the minimum $\left(1037.92 \mathrm{~kg} \mathrm{ha}^{-1}\right)$ under control $\left(\mathrm{V}_{0}\right)$. The increase in seed yield was obtained to the extent of $32.75,62.07$ and 79.68 per cent with the application of fortified vermicompost @ 2.0,4.0 and 6.0 t ha ${ }^{-1}$, respectively as compared to control.

Effect of sulphur: The application of sulphur significantly increased the seed yield over control. The maximum seed yield $\left(1609.50 \mathrm{~kg} \mathrm{ha}^{-1}\right)$ of mustard was recorded under treatment $\mathrm{S}_{60}$. However, seed yield obtained with treatments $\mathrm{S}_{40}$ and $\mathrm{S}_{60}$ was at par. The treatments $\mathrm{S}_{20}, \mathrm{~S}_{40}$ and $\mathrm{S}_{60}$ increased the yield to the extent of $13.85,24.02$ and 24.91 per cent, respectively as compared to control $\left(\mathrm{S}_{0}\right)$.

Interaction effect between vermicompost and sulphur on seed yield of mustard: Combined effect of levels of vermicompost and sulphur on seed yield was found to be significant (Table 2). Significantly higher seed yield was recorded with $6.0 \mathrm{t} \mathrm{ha}^{-1}$ fortified vermicompost in combination with $40 \mathrm{~kg} \mathrm{~S} \mathrm{ha}^{-1}$ (Table2). Minimum seed yield was recorded under control.

Nitrogen content

Effect of vermicompost: The nitrogen content in seed and stover increased significantly with increasing levels of fortified vermicompost. The maximum nitrogen content in seed $(4.17 \%)$ was found under the treatment
$\mathrm{V}_{6.0}$ and the minimum (3.07\%) nitrogen content was recorded under $\mathrm{V}_{0}$. The application of fortified vermicompost@2.0,4.0 and 6.0 t ha ${ }^{-1}$ increased the nitrogen content in seed to the extent of 14.33, 25.08 and 35.83 , respectively as compared to control.

Effect of sulphur: The effect of sulphur on nitrogen content in seed was found significant. The application of sulphur significantly increased the nitrogen content in seed as compared to control. However, the difference in nitrogen content under $\mathrm{S}_{40}$ and $\mathrm{S}_{60}$ treatments for seed was non-significant. The maximum value of nitrogen content $(3.96 \%)$ was recorded under treatment $\mathrm{S}_{60}$, while, minimum (3.09\%) under $\mathrm{S}_{0}$ in seed, respectively. Application of sulphur $\mathrm{S}_{20}, \mathrm{~S}_{40}$ and $\mathrm{S}_{60}$ increased the $\mathrm{N}$ content of seed to the extent of $16.50,28.01$ and 28.99 per cent, respectively as compared to control $\left(\mathrm{S}_{0}\right)$.

Interaction effect between vermicompost and sulphur on $\mathbf{N}$ content in seed of mustard: Table 3 showed that interaction effect between vermicompost $\mathrm{x}$ sulphur was found significant for $\mathrm{N}$ content in seed. Significant higher $\mathrm{N}$ content in seed was recorded with $40 \mathrm{~kg} \mathrm{~S}$ ha ${ }^{1}$ in combination with $6.0 \mathrm{t} \mathrm{ha}^{-1}$ vermicompost, which was signicantly superior to rest of the treatment combi- 
nations except $\mathrm{S}_{60}+\mathrm{V}_{6.0}$. The minimum $\mathrm{N}$ content in seed was found under control.

\section{Phosphorus}

Effect of vermicompost: The phosphorus content in seed increased significantly with increasing levels o fortified vermicompost. The maximum phosphorus content in seed $(0.929 \%)$ was found under the treatment $\mathrm{V}_{6.0}$ and minimum $(0.677 \%)$ under control $\left(\mathrm{V}_{0}\right)$. The application of fortified vermicompost @ 2.0,4.0 and $6.0 \mathrm{t} \mathrm{ha}^{-1}$ increased the phosphorus content of seed to the extent of $15.65,27.03$ and 37.22 per cent, respectively as compared to control.

Effect of sulphur: The effect of sulphur on phosphorus content in seed was recorded significant (Table7). The application of sulphur significantly increased to the phosphorus content in seed as compared to control. However, the difference in phosphorus content for the seed with treatments $S_{40}$ and $S_{60}$ was found nonsignificant. In seed maximum value of phosphorus content was recorded under $S_{60}$ and minimum under $\mathrm{S}_{0}$. Application of sulphur $\mathrm{S}_{20}, \mathrm{~S}_{40}$ and $\mathrm{S}_{60}$ increased the phosphorus content of seed to the extent of 17.39, 28.65 and 29.09 per cent, respectively as compared to control $\left(\mathrm{S}_{0}\right)$

Interaction effect between vermicompost and sulphur on $P$ content in seed of mustard: Combined effect of levels of vermicompost and sulphur on P content in seed was found to be significant (Table 4).

The significantly higher $\mathrm{P}$ content in seed was recorded under $40 \mathrm{~kg} \mathrm{~S}^{-1}$ in combination with $4.0 \mathrm{t} \mathrm{ha}^{-1}$ vermicompost, which was signicantly superior to rest of the treatment combinations except $\mathrm{S}_{40}+\mathrm{V}_{6.0}$ and $\mathrm{S}_{60}+\mathrm{V}_{4.0}$. Minimum $\mathrm{P}$ content in seed was recorded when neither sulphur nor vermicompost was applied.

\section{Sulphur}

Effect of vermicompost: The critical examination of data presented in Table 7 showed that sulphur content in the seed increased significantly with increasing levels of fortified vermicompost. The maximum sulphur content in seed $(1.133 \%)$ was found under the treatment $\mathrm{V}_{6.0}$ and the minimum $(0.672 \%)$ under control $\left(\mathrm{V}_{0}\right)$. The application of fortified vermicompost @ 2.0, 4.0 and $6.0 \mathrm{t} \mathrm{ha}^{-1}$ increased the sulphur content in seed to the extent of $29.61,51.63$ and 68.60 per cent, respectively as compared to control.

Effect of sulphur: The perusal of the data in Table 7 revealed that the effect of sulphur on sulphur content in seed was found significant. The application of sulphur significantly increased the sulphur content in seed as compared to control. However, the difference in sulphur content under treatments $\mathrm{S}_{40}$ and $\mathrm{S}_{60}$ for seed and was observed non-significant. The maximum value of sulphur $(0.999 \%)$ content was recorded under $\mathrm{S}_{60}$, while, the minimum $(0.795 \%)$ under $\mathrm{S}_{0}$. Application of sulphur $\left(\mathrm{S}_{20}, \mathrm{~S}_{40}\right.$ and $\left.\mathrm{S}_{60}\right)$ treatments increased the sulphur content in seed to the extent of 14.46, 24.65 and 25.66 per cent, respectively as compared to control $\left(\mathrm{S}_{0}\right)$.
Interaction effect between vermicompost and sulphur on sulphur content in seed of mustard: Data mentioned in table 5 showed that Interaction effect between vermicompost $\mathrm{x}$ sulphur was found significant for S content in seed. Sulphur content in seed of mustard was found significantly higher with treatment combination of $40 \mathrm{~kg} \mathrm{~S} \mathrm{ha}^{-1}$ and $6.0 \mathrm{t} \mathrm{ha}^{-1}$ vermicompost, which was signicantly superior to rest of the treatment combinations except $S_{60}+V_{6.0}$. The minimum $S$ content in seed was found under $\mathrm{S}_{0} \mathrm{~V}_{0}$ treatment combination.

\section{Sulphur uptake}

Effect of vermicompost: It is evident from the data presented in Table 7 showed that sulphur uptake by seed of mustard increased significantly with increasing levels of fortified vermicompost. The maximum sulphur uptake by seed $\left(21.26 \mathrm{~kg} \mathrm{ha}^{-1}\right)$ was obtained under $\mathrm{V}_{6.0}$, while, the minimum $\left(7.05 \mathrm{~kg} \mathrm{ha}^{-1}\right)$ under $\mathrm{V}_{0}$. The application of fortified vermicompost @ 2.0,4.0 and $6.0 \mathrm{t} \mathrm{ha}^{-1}$ increased the sulphur uptake by seed to the extent of $71.34,144.39$ and 201.56 per cent, respectively as compared to control.

Effect of sulphur: Data pertaining to sulphur uptake mentioned in Table 7 showed that the application of sulphur significantly increased sulphur uptake by seed of mustard. The maximum value of sulphur uptake was recorded under $\mathrm{S}_{60}$ followed by $\mathrm{S}_{40}, \mathrm{~S}_{20}$ and $\mathrm{S}_{0}$ in seed. Application of sulphur $\left(\mathrm{S}_{20}, \mathrm{~S}_{40}\right.$ and $\left.\mathrm{S}_{60}\right)$ treatments increased the sulphur uptakeby seed to the extent of 28.90, 52.04 and 54.46 per cent, respectively as compared to control.

Interaction effect between vermicompost and sulphur on sulphur uptake by seed of mustard: Combined effect of levels of vermicompost and sulphur on sulphur uptake by seed was found to be significant (Table $6)$. The significantly higher S uptake by seed was recorded with treatment combination $40 \mathrm{~kg} \mathrm{~S}^{-1}$ and $6.0 \mathrm{t} \mathrm{ha}^{-1}$ vermicompost, which was signicantly superior to rest of the treatment combinations except $\mathrm{S}_{60}+$ $\mathrm{V}_{6.0}$. The minimum $\mathrm{S}$ uptake by seed was recorded when neither sulphur nor vermicompost was applied.

\section{DISCUSSION}

The increase in grain yield with the application of vermicompost might be due to the effect of vermicompost in improving the physical condition of soil, and providing balanced supply of nutrients required for proper growth and development of the crop. The results corroborate with finding of Singh and Singh (2006) conducted a field experiment at Bhartpur (Rajasthan) and observed that application of FYM@ $5 \mathrm{t} \mathrm{ha}^{-1}$ had significant effect on primary and secondary branches per plant of mustard over control. Akbari et al. (2010) recorded that the application of enriched compost @6 t/ha was proved better for obtaining maximum uptake of $\mathrm{N}, \mathrm{P}$ and $\mathrm{K}$ by soybean as well as groundnut and $\mathrm{P}$ and $\mathrm{K}$ uptake by sesame. Treatments involving enriched compost or vermicompost found beneficial in respect to availabil- 
ity of various nutrients at harvest. The increase in grain yield with application of S might be because of the fact that $\mathrm{S}$ activates some proteolytic enzymes, helps in synthesis of vitamins and carbohydrates which are translocated to reproductive structures. Similar findings were also reported by Jogi et al. (2009) that growth attributes increased significantly with increasing levels of sulphur up to highest level of $40 \mathrm{~kg} \mathrm{~S}$ ha ${ }^{1}$ and Kapur et al. (2010) reported that yield attributes like plant height, number of primary and secondary branches per plant, number of siliqua per plant, number of seeds per silique and test weight were recorded significantly higher with application of $60 \mathrm{~kg} \mathrm{~S}$ ha ${ }^{1}$.The increase in grain yield due to conjoint application of vermicompost and sulphur might be due to development of better nutritional environment of soil besides balance supply of nutrients throughout the entire growth period of the crop.

Significantly, improved N, P, K, and S contents in seed due positive influence of vermicompost application on nutrient content in mustard crop appears to be due to improved nutrient levels both in the root zone and plant system. Thus, positive impact of vermicompost application on both these aspects ultimately led to higher accumulation of nutrients. These results are in line with the findings of Akbari et al. (2010), Singh et al. (2007) and Singh et al. (2006). The increase in availability of these nutrients in the root zone coupled with increase in metabolic activity at cellular levels might have increased nutrient uptake and their accumulation in the vegetative plants parts. Improvement of metabolisms led to greater translocation of these nutrients to reproductive organs of the crop and ultimately increases their contents in seed. These results are in close conformity with those of Vasanthi and $\mathrm{Ku}$ marswamy (1999), and Rajkhowa et al. (2000). The nitrogen seed increased significantly with the increase in the level of sulphur. The $\mathrm{N}$ contents increased significantly upto application of $40 \mathrm{~kg} \mathrm{~S} \mathrm{ha}^{-1}$. As stated earlier that $\mathrm{S}$ is a most important constituent of amino acids, like: methionine, cysteine and cystine and also involved in synthesis of enzymes, auxins and other substances of physiological importance. These results are in agreement with the findings of Kumawat and Aswal (2005) who had reported that $\mathrm{N}$ in seed and stover of mustard was significantly influenced by application of $\mathrm{S}$ upto $75 \mathrm{~kg} \mathrm{ha}^{-1}$. The increase in $\mathrm{N}, \mathrm{P}, \mathrm{K}$, and $\mathrm{S}$ contents of mustard have also been reported by Akbari et al. (2010), Singh and Meena (2004), Kumawat and Aswal (2005), Piri and Sharma (2006), Syed et al. (2006) and Sharma et al. (2009). Significant increase $\mathrm{S}$ uptake due to application of vermicompost@6.0 ha ${ }^{-1}$ was recorded under present investigation. Increased uptake of S seems to be due to the fact that uptake of nutrients is a product of biomass and its nutrient content. Sharma et al. (2009) reported that the application of integrated nutrient management recorded significantly higher total uptake of S over the control. The sulphur contents and uptake in seed in- creased significantly with the increase in the level of sulphur. The favourable conditions for microbial as well as chemical activities due to addition of vermicompost integrated with other nutrients augmented the mineralization of nutrients and ultimately increased the available nutrient status of the soil. These results are in agreement with those of Jat and Mehra (2007) reported effect of sulphur and zinc on yield, macronutrient content in and uptake by mustard on Haplustepts and Zizala et al. (2008) conducted experiment at Anand loamy sand (Typic Ustochrepts), Gujarat, India. Sharma and Arora (2008) were conducted for two consecutive years during the rabi season in sandy loam soils of Jammu (north India) under rainfed conditions to study the effect of $\mathrm{S}$ through gypsum or pyrite either in natural or ground from among the different treatments, $\mathrm{S}$ application at $50 \mathrm{~kg} \mathrm{~S}^{-1}$ of ground gypsum recorded the significantly highest uptake, which lead to an increase of 30 and 29.8 per cent in the first and second year respectively, over the control.

\section{Conclusion}

As regards interactive effects of treatment, synergistic behavior was noted between $6.0 \mathrm{t}$ vermicompost $\mathrm{ha}^{-1}$ $40 \mathrm{~kg} \mathrm{~S} \mathrm{ha}^{-1}$ for seed yield, nitrogen, and phosphorus contents and also sulphur content and uptake by seed of mustard. The concomitant effect of $6.0 \mathrm{t}$ vermicompost $\mathrm{ha}^{-1}$ and $40 \mathrm{~kg} \mathrm{~S} \mathrm{ha}{ }^{-1}$ application was found highly pronounced on seed yield and sulphur content in seed of mustard.

\section{ACKNOWLEDGMENTS}

The authors are grateful to Sri Karan Nerandra Agricultural University for providing necessary facilities during research. We appreciate the support and help rendered by the scientific and technical staff of Sri Karan Nerandra Agricultural University.

\section{REFERENCES}

Ahmad A. and Abdin M.Z. (2000). Effect of sulphur application on lipid, RNA and fatty acid content in developing seeds of rapeseed (Brassica campestris L.). Plant Science, 150: 71-76.

Akbari, K.N., Sutaria, G.S., Vora, V.D., Hirpara, D. S., and Padmani, D.R. (2010). Response of oilseed crops to enriched vermicompost on Vertic ustochrept under rainfed conditions. An Asian Journal of Soil Science, 5: 172-174.

Aulakh, M.S., Pasricha, N.S. and Sahota, N.S. (1977). Nitrogen-sulphur relationship in brown sarson and Indian mustard. Indian Journal of Agricultural sciences, 47 (5): 249-25.

Economic survey (2013): Statistical Appendix. Ministry of Home Affairs. Government of India, A17-A19. Available at http://indianbudget.nic.in

Falk K.L., Tokuhisa J.G. and Gershenzon J. (2007): The effect of sulfur nutrition on plant glucosinolate content: Physiology and molecular mechanisms. Plant Biology, 9: 573-581.

Hassan F.U., Manaf A., Qadir G. and Basra S.M.A. (2007): 
Effects of sulphur on seed yield, oil, protein and glucosinolates of canola cultivars. International Journal of Agriculture and Biology, 9: 504-508.

Jackson, M.L. (1967). Soil chemical analysis. Prentice Hall of Indian Pvt. Ltd., New Delhi.

Jat, J.R., and Mehra, R.K. 2007. Effect of Sulphur and Zinc on Yield,Macronutrient Content and Uptake by Mustard on Haplustepts.Journal of the Indian Society of Soil Science, 55: 190-195.

Jogi, K.J. S., Parmeet Singh, Lal Singh, Vipin Kumar (2009). Effect of sulphur sources and levels on growth, yield attributes and yield of mustard (Brassica juncea). Environment and Ecology, 27: 823-826.

Johnson, C.M. and Ulrich, A. 1959. Analytical methods for use in plant analysis. California Agricultural Experiment Station Bulletin, 766.

Kamaraj, S., Singaravel, R., Elayaraja, D. and Vembu, G. (2010). Influence of micronutrients fortified organic manures on the growth and yield of rice in Coastal saline soil. An Asian Journal of Soil Science 5: 131-133.

Kapur, L.T., Patel, A.R., and Thakor, R.F. (2010). Yield attributes and yield of mustard (Brassica juncea $\mathrm{L}$. Czern and Coss) as affected by sulphur levels. An Asian Journal of Soil Science, 5: 216-217.

Kumar S., Verma S.K., Singh T.K. and Singh S. (2011): Effect of nitrogen and sulphur on growth, yield and nutrient uptake by Indian mus-tard (Brassica juncea). Indian Journal of Agricultural Sciences, 81: 145-149.

Kumawat, B.L. and Aswal, S. (2005). Effect of sulphur and zinc fertilization on growth, yield, nutrient uptake and quality of mustard. National Symposium on Stress Management pp. 119.

Patel G.M., Patel B.T., Dodia I.N., Bhatt V.K. and Bhatt R.K. (2009): Ef-fect of sources and levels of sulphur on yield, quality and nutrient uptake of mustard (Brassica juncea L.) varieties in loamy sand soil. Journal of Soils and Crops, 19: 30-35.

Piri I., Nik M.M., Tavassoli A. and Rastegaripour F. (2011): Effect of irrigation intervals and sulphur fertilizer on growth analyses and yield of Brassica juncea. African Journal of Microbiology Research, 5: 3640-3646.

Piri, ISSA; Sharma, S. N. (2006). Effect of levels and sources of sulphur on yield attributes, yield and quality of Indian mustard (Brassica juncea). Indian Journal of Agronomy, 51: 217-220.

Rajkhowa, D.S., Gogoi, A.K., Kandali, R. and Rajkhowa, K.M. (2000). Effect of vermicompost on greengram nutrition. Journal of Indian Society of Soil Science, 48:
207-208

Sharma, K. R. and Arora, S. (2008). Effectiveness of gypsum and pyrite for sulphur fertilization on yield and quality of Indian mustard under rainfed conditions of North India. Communications in Soil Science and Plant Analysis, 39: 2431-2439.

Sharma, A, Sharma, P., Brar, M.S. and Dhillon, N.S. (2009). Comparative Response to Sulphur Application in Raya (Brassica juncea) and Wheat (Triticum aestivum) grown on Light Textured Alluvial Soils. Journal of Indian Society of Soil Science, 57: 62-65

Singh, A. and Meena, N.L. (2004). Effect of nitrogen and sulphur on growth, yield attributes and seed yield of mustard. (Brassica juncea) in eastern plains of Rajasthan. Indian Journal of Agronomy, 49: 126-128.

Singh, R. and Singh, S.K. (2006). Evaluation of yield and quality aspects of Indian mustard (Brassica juncea (L.) Czern and Coss) under integrated nutrient management. Annals of Agricultural Research New Series, 26: 448451.

Singh, S., Mehta, A.K. and Thakral, S.K. (2007). Nutrient content and their uptake in wheat as affected by vermicompost and inorganic fertilizers. Haryana Journal of Agronomy, 23: 106-108.

Snell, F.D. and Snell, C.T. (1971). Calorimetric methods of analysis. $3^{\text {rd }}$ Edn. Vol. II D. Van. Nostrand Inc. New York.

Swarup, A. and Wanjari, R.H. (2000). Three decades of All India Co-ordinated Research Project on long term fertilizer experiment to study, changes in soil quality crop productivity and sustainability. Indian Institute of Soil Science, Bhopal, India, 59.

Syed, T.H., Ganai, M.R., Tahir, A. and Mir, A.H. (2006). Effect of Nitrogen and Sulphur fertilization on yield of and Nutrient Uptake by Sunflower. Journal of Indian Society of Soil Science. 54: 375-376.

Tabatabai, M.A. and Bremmer, J.M. (1970). A simple turbidometric method of determining total sulphur in plant material. Agronomy Journal, 62: 805 - 806.

Vasanthi, D. and Kumaraswamy, K. (1999). Efficacy of vermicompost to improve soil fertility and rice yield Journal of Indian Society of Soil Science, 47: 268-272.

Zizala, V.J., Jadav, N.B., and Gorfad, P.S. (2008). Effect of sulphur and zinc on yield, quality and its concentration on mustard. Asian Journal of Soil Science, 3: 173-177. 